\title{
Socio-economic stabilizing mechanisms for socio- environmental-economic system with low stability level
}

\author{
Elena Petrova \\ Volgograd State University \\ Institute of management and regional economics \\ Volgograd, Russia \\ ea_petrova@mail.ru
}

\author{
Alla Kalinina \\ Volgograd State University \\ Institute of management and regional economics \\ Volgograd, Russia \\ allakalinina@yandex.ru
}

\author{
Alexander Voronin \\ Volgograd State University \\ Institute of mathematics and information technologies \\ Volgograd, Russia \\ voronin.prof@gmail.com
}

\begin{abstract}
This paper presents the results of developing the mechanism of environmental-economic stabilization of environmental-economic systems (EES) with low stability. In today's post-crisis conditions of the ongoing recession and the effects of economic sanctions Russian regions are faced with serious social, economic and environmental negative impacts of economic activity: the depletion of the natural resource factor and, as a consequence, declining in quality of life of the population. These problems are particularly acute in the environmental-economic systems where natural resources act as a system-forming factor. The main management task for such environmentaleconomic systems with low stability is the development of management mechanisms, aimed at the preservation and rational use of the main (and sometimes only) production resource of the area. The article proposes a classification based on the degree of internal stability of economic systems. Authors propose a unified approach to mechanism developing by identifying the impact factors (using PEST + E analysis), creating the signed digraph of interfactoral interactions and graph connectivity matrix of the dynamics of the main factor interaction, EES state model with indicator assessment (the vertices) as well as environmental monitoring and monitoring of socioeconomic development of the territory based on unified methodology system. Authors propose a system of indicators to assess the intensity of economic processes and the social life of the population of such environmentaleconomic systems with low stability.
\end{abstract}

Keywords - regional economy, ecological and economic management, systems with low stability level, territorial management mechanism, instruments of ecological and economic management

\section{INTRODUCTION}

The concept of long-term socio-economic development of the Russian Federation for the period up to 2020 [1], published in 2008, meets various obstacles in the process of its implementation. An unspecified wording of the Concept do not reveal the algorithms of its implementation in specific environmental-economic systems (EES) that are characterized by their spatial distribution, natural and socio-economic uncertainty, multiscale nature and complexity of the dynamic processes and require the local authorities to create their own strategic plans for implementation of the tasks of the Concept.

In today's post-crisis conditions of the ongoing recession and the effects of economic sanctions Russian regions are faced with serious social, economic and environmental negative impacts of economic activity: the depletion of the natural resource factor and, as a consequence, declining in quality of life of the population. These problems are particularly acute in the environmental-economic systems where natural resources act as a system-forming factor. The main management task for such environmental-economic systems with low stability is the development of management mechanisms, aimed at the preservation and rational use of the main (and sometimes only) production resource of the area. [2] The main analytical component of such a mechanism is the models of natural dynamic reproduction, which include the determination and assessment of endogenous factors that determine the equilibrium of such systems, their interaction, as well as the determination of negative and compensatory exogenous variables. 
The problems of management are particularly acute in the environmental-economic systems with high environmental risks where natural resources act as a system-forming factor (river-water, rain-water, humus, produced by floods, amount of solar energy). Thus such environmental-economic systems represent systems with low stability level that are understood as territorially detached open economic systems with positive and negative feedback, multifactor dependence on systemforming natural resources (limiting factor of an ecosystems) and high threshold sensitivity to its spatiotemporal fluctuations. As a consequence these systems have high spatiotemporal heterogeneity and uncertainty. Destabilization of the environmental-economic system with low stability level may be caused by disruption of its economical system and of the mechanisms of its reproduction: the systematic regular expropriation of the system-forming resources of the economic system leads to a decrease in its dynamic stability and increasing environmental risks.

The mechanism of environmental and economic management should be aimed at reducing the negative externalities arising from the involvement of a natural resource in economic activities, its depletion, as well as ensuring a balance of interests of all participants in the economic process:

- economic territorial system, in particular, economic entities - in obtaining the necessary quantity and quality of resources to maximize profits;

- biosphere - in reducing negative impacts to a level that provides the possibility of its natural recovery;

- population of that territory - in creating comfortable living conditions;

- executive bodies of the region - in ensuring the necessary level of natural resource, economic, environmental and other types of security and quality of life.

The main functions of the mechanism are: optimal adjustment and balance of elements of rational environmental management in the region; development of incentive tools for the management system (such as the implementation of technical standard and quotas for the consumption of natural resources, etc.) aimed at ensuring enhanced reproduction and environmental responsibility; planning and control of technical and organizational measures ensuring equilibrium in the environment of the regional economic system; arrangement of conditions for stabilizing the assimilation capacity of the territory.

\section{MATERIALS AND Methods (MODEL)}

Examples of an environmental-economic system with low stability level are the floodplains of major rivers in the period of their active development after the construction of hydroelectric power stations. Floodplain landscapes of rivers are determined by the area relief, the flood cycle, river flow rate, soil composition, climate, etc., with the first three factors being the main structure-forming factors. As a small part of the large river basins with a cyclic hydrological regime, they have unstable riverbed dynamics described by the hysteresis processes. The relief of the floodplains area and the structure of the small riverbeds are characterized by spatiotemporal heterogeneity, and high local variability at constant average aggregative spatiotemporal characteristics. This instability is the cause of the biodiversity of floodplains. At the same time high water-level peaks maintain the balance of floodplain ecosystems and limit the socio economic development of their territories by the individual small livestock farms (first economic structure).

A modification of the hydrological regime of a large river after launching a hydroelectric power station starts the process of restructuring the floodplain landscape, a natural environment in which a territorial environmental-economic system functions. The drastic decline in the average volume and maximum flood values and, accordingly, the flood area cause a progressive deterioration of a riverbed system and further reductions in this area and at the same time stimulate the active socio economic development of the liberated moisture-rich fertile soils. This creates socio economic (agricultural) structure of the second generation, followed by the anthropogenic relief transformation of the territory and floodplain riverbed systems which adopt its hydrological regime to the economic conditions.

The growth in demand for electricity, the need to maintain a constant level of the river at a variable annual river flow stimulate further growth of the low-water bed and, consequently, a reduction of flood flows that activates the degradation processes in the floodplain. Thus, the degradation of the riverbed structure and floodplain nature, accelerated by the socio economic activity, causes a progressive reduction of stored soil moisture and the degradation of the agricultural economic structure, whereas the socio economic infrastructure provides the basis for the development of the third (urbanization) economic structure: building development of rural areas and further reduction of the flood volume in order to ensure the safety of the growing population of the floodplain.

The proximity of major cities accelerates the socio economic development of floodplain areas and imposes upon them additional recreational load. The uniqueness of floodplain nature determines its commercial and ecological importance, these areas often have a status of particularly valuable and protected (reserves and natural parks). Environmental degradation of these areas expressed in the disappearance of many valuable species of flora and fauna, is an ecological and humanitarian issue. Finally, chaotic economic transformation of spatially inhomogeneous area relief and riverbed structure of the floodplain by interdependent agents in conditions of a degrading variable hydrological regime creates an objective basis of interfarm conflicts.

Volga-Akhtuba floodplain situated in Volgograd Oblast, Astrakhan Oblast and the Republic of Kalmykia is one of these socio-economic environmental systems with low stability level. Volga-Akhtuba floodplain is a unique natural formation in the semidesertic steppe zone in the south of 
Russia, the last, practically the only part of Volga valley that is preserved in its natural form. Volga-Akhtuba floodplain is a particularly valuable and integral natural and territorial formation that is remarkable for its high biodiversity, the presence of rare and vulnerable in the given conditions plants and animal species, landscapes and favorable conditions for ecotourism development.

According to the Resolution of the Head of Volgograd Region Administration no. 917 dated 17.06.2010 [3] the Volga-Akhtuba floodplain area has a status of regional Natural Park. According to this Resolution the National Park area is a specially protected natural reservation of regional significance under the jurisdiction of executive authorities of Volgograd Oblast. Volga-Akhtuba floodplain is an example of an area with a high stratification level and environmental instability. Natural landscape of the floodplain is determined by the spring flood that affects a significant part of its lowland area. The construction of large hydro-electric power-plants and reservoirs on the river Volga caused a considerable damage to the ecosystem of the Lower Volga region and Volga-Akhtuba floodplain, resulted in sediment run-off dysfunction and change in bed-forming processes. Under conditions of high degree of flow control in Volga River the spring flood in Volga-Akhtuba floodplain is entirely regulated by the water pass through the damsite of Volga Hydroelectric Station.

The construction of transport infrastructure leads to the problem of preservation of the natural park - enhancing urbanization of the territory in the last years. There are to observe illegal land development as well as the removal of part of its territories, adjacent to existing settlements and infrastructure (new masterplans of municipalities located on the floodplain area are being approved).

Mutually enhancing infrastructure and urbanization factors contribute to further reduction of flooding and, consequently, force degradation of the floodplain nature.

Thus, there is a sharp competition in the floodplain areas between the subjects, the subsystems of the EES for the distribution of the degrading system-forming water resource in conditions of environmental uncertainty, the consequence of which is the growth of socio-economic and environmental instability and risks. The problem of designing mechanisms for the ecological and economic stabilization of environmental-economic systems with low stability is acute for the management of such territories.

\section{RESULTS AND DISCUSSION}

Classification of environmental-economic system stability. The degree of internal EES stability is determined by a variety of properties of mutual sensitivity and adaptability of different components of its natural and socio-economic subsystems. A potential source of instability is a high degree of EES structure complexity: it implies sources of natural and man-induced danger, highly urbanized areas and valuable ecosystem elements that under conditions of high environmental instability increase its internal conflict intensity and, therefore, instability. Ratio of mutual adaptability pace is important for stabilization of these systems. In dynamically stable EES economical adoptability to the environmental degradation represents a part of socio-economic technology and the adaptation of economical subsystem to slow environmental degradation it is represented in the form of economic innovation. The difference in rates of the nature adaptation and the formation of local economic system causes internal EES instability.

Stability properties in an open system are determined by the combination of its sensibility and adaptability. Authors formalize the analyses of the EES stability through the application of two-level assessment ('high' and 'low') of the sensibility and the adaptability of the system which allows determining three types of internal stability of each subsystem. Let us introduce the following types of ESS stability: statistical stability (SS) that represents low sensibility of one subsystem to the state of another; dynamic instability/stability (DI/DS) that represents high sensibility/adaptability of one subsystem to the state of another.

All possible states of ESS are a combination of high sensitivity with low/high adaptability (see Table 1), the first four states of which represent internally stable, and the next five internally unstable nature-economic systems.

TABLE 1 POSSIBLE STATES AND STRUCTURE PROPERTIES OF NATURE-ECONOMIC SYSTEM STABILITY

\begin{tabular}{|c|c|c|c|}
\hline $\begin{array}{l}\text { SEES } \\
\text { stabili } \\
\text { ty }\end{array}$ & $\begin{array}{l}\text { Econo } \\
\text { mic } \\
\text { subsy } \\
\text { stem } \\
(\mathrm{EcS})\end{array}$ & $\begin{array}{l}\text { Envir } \\
\text { onme } \\
\text { ntal } \\
\text { subsy } \\
\text { stem } \\
(\text { EnS) }\end{array}$ & SEES structure properties \\
\hline+ & SS & SS & Weakly interactive quasi-stable EcS and EnS \\
\hline+ & SS & DS & $\begin{array}{l}\text { Less-developed EcS as a part of a stable } \\
\text { ecosystem }\end{array}$ \\
\hline+ & DS & SS & $\begin{array}{l}\text { Adaptive EcS and an non-sensitive high- or } \\
\text { low-stable EnS }\end{array}$ \\
\hline+ & DS & DS & $\begin{array}{l}\text { Developed stable EcS in adaptive interaction } \\
\text { with a stable ecosystem }\end{array}$ \\
\hline$+/-$ & DI & SS & $\begin{array}{l}\text { Non-adaptive EcS sensible to EnS state and } \\
\text { non-sensible to EcS state. The actual stability } \\
\text { of the EcS in interaction with the EnS is } \\
\text { determined by its external stability: in the case } \\
\text { of weak external stability of the EnS, the } \\
\text { nature and economic system is unstable, and } \\
\text { conversely, with strong EnS stability, the } \\
\text { economic instability does not affect the system } \\
\text { and the ESS is stable }\end{array}$ \\
\hline- & SS & DI & Retrogressive EnS and low sensible EcS \\
\hline- & DI & DS & $\begin{array}{l}\text { Stable dynamic EnS and a EcS retrogressive } \\
\text { as a consequence of high basic resource } \\
\text { fluctuations }\end{array}$ \\
\hline- & DS & DI & Retrogressive EnS and adoptive EcS \\
\hline- & DI & DI & $\begin{array}{l}\text { Retrogressive interdependent } \mathrm{EcS} \text { and } \mathrm{EnS} \text { as } \\
\text { a consequence of deterioration of reproduction } \\
\text { mechanisms of the EnS by the EcS }\end{array}$ \\
\hline
\end{tabular}

Stabilization mechanisms for EES with low stability level. Proposed classification of stability properties of environmental-economic systems is the base for developing stabilization mechanisms. EES internal stabilization can be performed through the natural or artificial change of components, structure and functions of its unstable subsystems 
aimed at decreasing their sensibility or increasing their adoptability if its internal interactions that is reversing their instable code (5-9) in one of the stable ones (1-4) (see Table $1)$.

Further designing of stabilization mechanisms for an EES with low stability level involves the allocation of the factors that have the greatest influence on the internal stability. The choice of factors is based on the structuring (conceptualization) of data on the socio-economic situation in the Volga-Akhtuba floodplain with the use of PEST + Eanalysis (Politicy, Economy, Society, Technology, Ecology analysis) [4], which involves the identification of five main groups of factors (political, economic, social, technological and environmental), on which the external and internal environment of the system is analyzed.

The list of factors, the assessment of the orientation and significance of the influence of each individual factor was carried out on the basis of the processing of expert assessments and the ranking of factors by the degree of significance for the object under study in the problem situation.

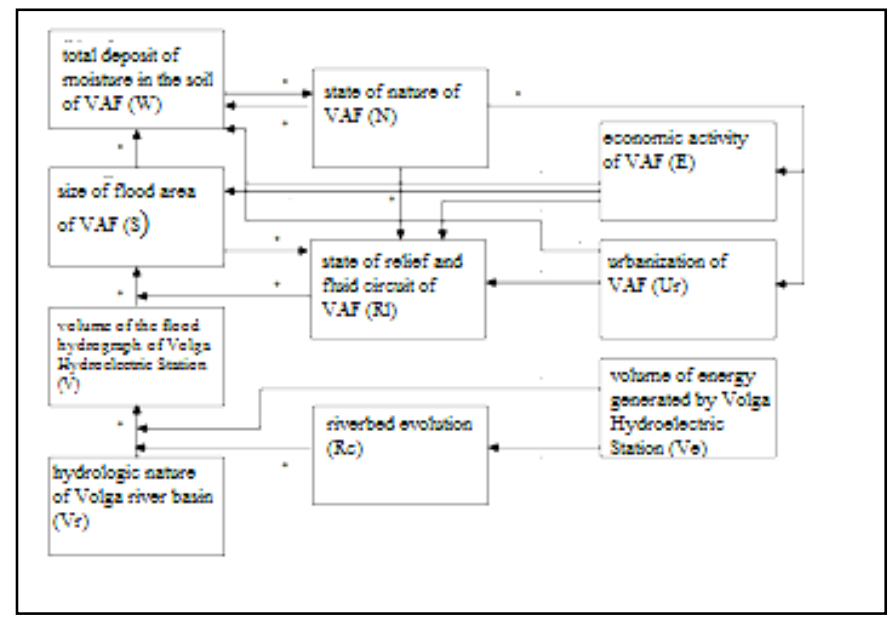

Fig. 1 Directed graph of interfactoral interaction for VolgaAkhtuba floodplain

\section{CONCLUSION}

Figure 1 shows the final directed graph of interfactor interaction for the Volga-Akhtuba floodplain, which allows us to determine the following classes of stabilization mechanisms:

- (0) composition change (adding and / or removing) vertices and their corresponding edges;

- (1) external institutional or organizational restriction of economic development (reduction of positive changes in relevant vertices by direct prohibitory injunction or a permanent high fees for the use of natural resources);

- (2) organizational and technological changes that remove from the graph of economic-environmental interactions the edges of negative economic influences on the natural system (or severely reduce them by compensating actions);
- (3) organizational and technological changes that add to the interaction graph edges of inverse stabilizing positive links that compensate negative economic impacts on the natural system.

Empirical analysis allows us to distinguish the following (natural and artificial) tools of the stabilization mechanisms of EES.

Class (0):

1. Degradation of a part of the natural system - possible internal stabilization of the system by the disappearance of all DI elements from it and / or possible external stabilization of the economic system by isolating it from the destabilizing effects of the natural system. Note that this mechanism can also potentially reduce the stability of the EES, due to the forced degradation of part of the economic subsystem, as the result of deprivation of the production resource factor, as well as the reduction of natural diversity in the long term.

2. Diversification of resources and types of economic activity - possible internal stabilization of the economic subsystem by expanding the area of effective performance and reducing its dependence on critical natural resources.

Class (1):

3. Reduction (restriction or prohibition) of certain types of economic activity - possible external stabilization of the natural subsystem by reducing the intensity of destabilizing effects.

Class (2):

4. Use of environment friendly technologies and compensating actions (transition to alternative resources and production models) - possible external stabilization of the natural system by reducing (eliminating) destabilizing impacts and applying compensatory measures and / or possible internal stabilization of the economic subsystem by reducing (eliminating) its dependence on natural resource.

5. Projects of environmental remediation (nature substitution) - restoration of the composition (variety) and / or structure of the natural subsystem that increase the efficiency of its reproductive processes.

Class (3):

6. Mechanisms of environmental and economic management of economic agents - the formation of sensitivity and adaptability of the economic subsystem to the state of the natural subsystem by appropriate economic stimulation of economic agents in combination with external stabilization of the natural subsystem by reducing the destabilizing effects to the acceptable level.

On the basis of the interfactor interaction digraph (see Figure 1), in order to quantitatively measure these interactions and determine the directions of administrative influences 
within the framework of the stabilization mechanism, it is necessary to estimate the values that characterize the vertices of the graph (for the Volga-Akhtuba floodplain): the annual river flow; the volume of spring flood in the floodplain of the river; the indicator of the carrying capacity of the hydraulic system of the floodplain; the area the flood; deposit of moisture in the soil; the indicator of the ecosystem state in the floodplain; volume of energy generated by Hydroelectric Station; the level of socioeconomic activity in the floodplain; the indicator of socio-economic changes in the relief of the floodplain; efficiency of socioeconomic activities in the floodplain; the area of socioeconomic lands; the urbanization level of the Volga-Akhtuba floodplain; the population of the floodplain; the level of hydrological safety in the floodplain; the indicator of the quality of life in the floodplain.

Measurement of indicators characterizing the state of the natural subsystem is carried out during environmental monitoring. [5]

It is advisable to collect and analyze the indicators characterizing the state of the economic subsystem in the course of monitoring the socio-economic development of the territory. [6] Some of indicators in this system are generalizing indicators (the level of socioeconomic activity in the floodplain, the efficiency of socioeconomic activities in the floodplain, the level of urbanization of the Volga-Akhtuba floodplain, the indicator of the quality of life in the floodplain), that requires their further decomposition. The main problem arising during the monitoring is the lack of transparency and availability of the proposed indicators. The data collected by the territorial body of the Federal State Statistics Service very narrowly reflect the processes under investigation, especially at the level of municipalities (municipal settlements), which requires additional costs for carrying out the monitoring. Therefore, for example, when assessing the socioeconomic activity of the territory, it is not possible to use the generally accepted system of measurement in the regional economy (gross product, shipping volume, investments, and employment of the population) and it is necessary to use relative indicators of the intensity of economic processes and social life of the population.

Thus, the proposed indicators can be evaluated through the following available statistics of rural settlements:

Urbanization level of the Volga-Akhtuba floodplain - total area of the lands of the municipal union (MU); total length of streets, driveways; length of public roads; the number of issued building permissions; commissioning of residential buildings on the territory of the municipality; the number of issued permits to commission facilities; the total area of living quarters;

The level of socioeconomic activity in the floodplain - the indicator of the autonomy of local budgets (the share of own revenues in the aggregate amount of the budget of the settlement), the indicator of fiscal capacity (income of the settlement budget per capita), the value of local budget revenues per unit area of the settlement territory, population growth / decline, retail facility per 1,000 population;
The indicator of socio-economic changes in the topography of the floodplain - the size of dispersion of the indicators of socioeconomic activity;

The efficiency of socioeconomic activities in the floodplain - the ratio of per capita incomes of the population to the fiscal capacity of the settlement;

The area of socio-economic lands - the total area of land within the boundaries of the locality (for all functional areas);

The indicator of the quality of life in the floodplain - the income of the population per capita, the provision of municipal services (the number of educational organizations per 1000 population, the number of hospital organizations per 1000 population, the number of sports facilities per 1000 population), the average spending per capita of the settlement budget for "Housing and public utilities".

Integration of the indices for individual blocks is carried out by standardized by the maximin method and the use of the additive formula.

Thus, the main scientific and practical results lie in a unified approach to the construction of a mechanism for stabilizing environmental-economic systems with low stability by identifying the influence factors (using PEST + E-analysis), the construction of a signed digraph of interfactor interactions and the connection matrix of the interaction graph of the main factors dynamics, a model of the state of the EES with an assessment of indicators (graph vertices), as well as environmental monitoring and monitoring of socio-economic development of the area using unified methods.

On the basis of the obtained models and assessments of control values, it can be said that the implementation of this mechanism requires the implementation of environmental remediation projects (forest-, fish-, riverbed- restoration) and nature substitution (laying artificial channels and reservoirs), and environment-friendly projects of urbanization.

The systemic effect is provided by the merging of classes (1) and (2) or classes (2), (3), when the mechanisms of class (3) compensate for the residual diffused effect of factors after the implementation of mechanisms (2). The classes (1) and (3), obviously, are incompatible.

The economic instruments of the proposed stabilization mechanism are the following: the establishment of an optimal fees for natural resources consumption to fully compensate the negative impacts; optimal distribution of fees between economic entities so that the sum of optimal actions for the subject would give in total the planned value of consumption of each resource; development of a special program for external management (consumption monitoring, increasing production efficiency and implementation resource-conscious production technologies, closure of an enterprise in case of failure to implement the two previous measures) for economic entities exceeding the acceptable range of negative impact on the natural subsystem; the development of a targeted program for co-financing of environmental remediation projects (narrowing of riverbed, clearing and deepening the channels of the floodplain) and projects for supplementing the natural channel system with an artificial channel (channels, 
floodgates, mini-vaults, etc.) to ensure the ecological and economic hydrological regime, minimize the risk of drought and catastrophic flooding.

\section{References}

[1] O Concepts of long-term social and economic development of the Russian Federation for the period until 2020 (with amendments and additions) // Order of the Government of the Russian Federation of November 17, 2008 $\mathrm{N}$ 1662-p [O Koncepcii dolgosrochnogo social'noehkonomicheskogo razvitiya RF na period do 2020 goda (s izmeneniyami i dopolneniyami) //Rasporyazhenie Pravitel'stva RF ot 17 noyabrya 2008 g. N 1662-p]

[2] Petrova E., Shevandrin A., Kalinina V. Effectiveness of State Territorial Administration in Provision of Sustainable Economic Growth of the Region // Integration and Clustering for Sustainable Economic Growth // Contributions to Economics. Special Issue - 2017. - c. 383 - 399.

[3] Resolution of the Head of the Administration of the Volgograd Region No. 917 of 17.06.2011 "On the approval of the Regulations on the Volgo-Akhtuba Floodplain Nature Park." - Access mode: http://base.garant.ru/20167181/ [Postanovlenie Glavy Administracii Volgogradskoj oblasti № 917 ot 17.06 .2011 «Ob utverzhdenii polozheniya o prirodnom parke Volgo-Ahtubinskaya pojma». - Rezhim dostupa: http://base.garant.ru/20167181/]
[4] Avdeeva Z.K., Kovriga S.V. Heuristic method of conceptual knowledge structuring in formalization of weakly structured situations on the basis of cognitive maps. // Management of large systems. Issue 31. - Moscow: IPM RAS, 2010 - C. 5-35. [Avdeeva Z.K., Kovriga S.V. EHvristicheskij metod konceptual'noj strukturizacii znanij pri formalizacii slabostrukturirovannyh situacij na osnove kognitivnyh kart //Upravlenie bol'shimi sistemami. Vypusk 31. - M.: IPU RAN, 2010. S. 5-35]

[5] Voronin AA, Vasilchenko AA, Pisareva MV, Pisarev AV, Khoperskov AV, Khrapov SS, Podshchikova Yu.E. Designing of the system of ecological and economic management of the territory of the Volga-Akhtuba floodplain on the basis of hydrodynamic and neoinformational modeling // Management of large systems. Issue 55. Moscow: IPM RAS, 2015. C.79-102. [Voronin A. A., Vasil'chenko A.A., Pisareva M.V., Pisarev A.V., Hoperskov A.V., Hrapov S.S., Podshchipkova YU.E. Proektirovanie sistemy ehkologoehkonomicheskogo upravleniya territoriej Volgo-Ahtubinskoj pojmy na osnove gidrodinamicheskogo i neoinformacionnogo modelirovaniya // Upravlenie bol'shimi sistemami. Vypusk 55. M.: IPU RAN, 2015. S. 79-102]

[6] Petrova, E.A. Monitoring of the socio-economic development of the territory, taking into account the results of management and development risks. / E.A. Petrova // Regional economy. South of Russia. - 2015. - No. 1 (7). - P. 51-59. [Petrova, E.A. Monitoring social'no-ehkonomicheskogo razvitiya territorii s uchetom rezul'tatov upravleniya i riskov razvitiya. /E.A. Petrova // Regional'naya ehkonomika. YUg Rossii. - 2015. - № 1 (7). - S. 51-59.] 